\title{
Redefining scope: the true environmental impact of smartphones?
}

\author{
James Suckling $^{1}$ (1) $\cdot$ Jacquetta Lee $^{1}$
}

Received: 3 September 2014 / Accepted: 19 May 2015 / Published online: 10 June 2015

(C) The Author(s) 2015. This article is published with open access at Springerlink.com

\begin{abstract}
Purpose The aim of this study is to explore the literature surrounding the environmental impact of mobile phones and the implications of moving from the current business model of selling, using and discarding phones to a product service system based upon a cloud service. The exploration of the impacts relating to this shift and subsequent change in scope is explored in relation to the life cycle profile of a typical smartphone.

Methods A literature study is conducted into the existing literature in order to define the characteristics of a "typical" smartphone. Focus is given to greenhouse gas (GHG) emissions in different life cycle phases in line with that reported in the majority of literature. Usage patterns from literature are presented in order to show how a smartphone is increasingly responsible for not only data consumption but also data generation. The subsequent consequences of this for the balance of the life cycle phases are explored with the inclusion of wider elements in the potential expanded mobile infrastructure, such as servers and the network.

Results and discussion From the available literature, the manufacturing phase is shown to dominate the life cycle of a "typical" smartphone for GHG emissions. Smartphone users are shown to be increasingly reliant upon the internet for provision of their communications. Adding a server into the scope of a smartphone is shown to increase the use phase
\end{abstract}

Responsible editor: Walter Klöpffer

James Suckling

j.suckling@surrey.ac.uk

1 Centre for Environmental Strategy, Faculty of Engineering and Physical Sciences, University of Surrey, Guildford, Surrey GU27XH, UK impact from 8.5 to $18.0 \mathrm{~kg} \mathrm{CO}_{2}$-eq, other phases are less affected. Addition of the network increases the use phase by another $24.7 \mathrm{~kg} \mathrm{CO}_{2}$-eq. In addition, it is shown that take-back of mobile phones is not effective at present and that prompt return of the phones could result in reduction in impact by best reuse potential and further reduction in toxic emissions through inappropriate disposal.

Conclusions The way in which consumers interact with their phones is changing, leading to a system which is far more integrated with the internet. A product service system based upon a cloud service highlights the need for improved energy efficiency to make greatest reduction in GHG emissions in the use phase, and gives a mechanism to exploit residual value of the handsets by timely return of the phones, their components and recovery of materials.

Keywords Greenhouse gas $\cdot$ Life cycle assessment $\cdot$ Mobile phone $\cdot$ Product service system $\cdot$ Scope $\cdot$ Smartphone $\cdot$ User profiles

\section{Introduction}

The mobile phone has been one of the most disruptive technologies to personal connectivity with the wider world since its introduction in the early 1980s. Ever increasing miniaturisation and power of the components, along with improving data bandwidth of the supporting infrastructure, has allowed the mobile phone to become a device capable of far more than just voice calls. This is particularly true of the smartphone. Although smartphones have existed for almost two decades, it was not until the advent of Apple's iPhone in 2007 that the concept reached the attention of a truly broad consumer audience, by offering a superior mobile internet experience (West and Mace 2010). Now, smartphones are fast 
becoming the dominant communication device on the planet, comprising over half of new sales in 2013 (Gartner 2013).

The rapid development of mobile phones has led to a market based upon an almost equally rapid replacement of older devices. The high turnover of devices is exacerbated by the fact that they are often not disposed of responsibly (Tanskanen 2013). Mobile phones require many rare and precious metals in their construction (OECD 2010), leading to a potential irretrievable loss of resource. While it will be shown that it is beneficial to recapture these metals, the current business model relies upon third party businesses to collect old phones (Ongondo and Williams 2011b). Product service systems (PSS) are one mechanism by which resources can be retained through the provision of a service by a provider who has an interest in retention of the product itself (Beuren et al. 2013). Applying a PSS to mobile phones may offer mechanisms to facilitate the return of the phones and components for timely reuse, remanufacture or recycling. A potential PSS for mobile phones is one in which the functionality we associate with smartphones, the high end processors and large amounts of memory, are outsourced to a remote computer. Mobile cloud computing is an emerging area for research (Abolfazli et al. 2013). Although challenges remain, in principle, it may be utilised, leading to potential simplification of the handset itself and reduction in energy consumption by outsourcing the intensive computation resources to hardware across a network. The reduction of energy consumption and greater robustness of any take-back scheme has the potential to reduce environmental impact. The simplification of the mobile handset and outsourcing of heavy processing could lead to an increased lifetime of the handset with further associated reduction in environmental impact. It has been demonstrated that it may be true for thin client computers (Andrae 2013), but does this still hold true for mobile phones? This article will explore the potential hidden environmental impacts or benefits that may arise from implementation of such a PSS. The purpose of this article is to explore the implications of chancing the boundary conditions of a mobile phone to incorporate the basic components of a cloud-based system. Section 2 reviews the existing LCA literature of mobile phones, followed in Sect. 3 by a representation of the life cycle profile of a "typical" smartphone. Section 4 explores the lifetime of mobile phones. The changing landscape of the user profile is discussed in Sect. 5. The effect of adding a server to the life cycle is presented in Sect. 6, a network in Sect. 7 and charging behaviours in Sect. 8. The end of life phase is explored in Sect. 9. Concluding remarks are offered in Sect. 10.

\section{Summary of literature dedicated to mobile phones}

The mobile phone represents a unique incursion of technology into the life of consumers, providing a level of integration and interaction with a wider social and technological sphere possibly unequalled by any other technology. This is reflected in the continually increasing sales of mobile phones and more recently the growing market share of the more advanced smartphones with their enhanced functionality (Ericsson 2013), where the increase is driven both by opening up of new markets in developing countries and an ever increasing set of facilities and processing power. A number of studies have explored the environmental impact of mobile phones across their life cycle. The majority report the impact in terms of greenhouse gas (GHG) emission or energy (Apple 2013a, b; Ercan 2013; Frey 2002; Herrmann 2008; HTC 2013; Guvendik 2014; Nokia 2013a, b, c; Singhal 2005; Wright 1999; Yu et al. 2010). Many of these references claim to be conducted in accordance with ISO 14040:2006 (2010a) and 14044:2006 (2010b), the exceptions appearing to be Frey (2002), Wright (1999), Yu et al. (2010) and Guvendik (2014). The references from Nokia in addition refer to more specific sets of guidelines relating to information and communication technology (ICT): ETSI TS 103199 (2011) and UTIT L 1410 (2012). Of the above references, those from Apple, HTC and Nokia are product declarations made publicly available in support of a particular mobile phone model. Singhal (2005) is a report made on behalf of Nokia by an employee. Wright (1999) is an EngD thesis based upon Nokia phones, part supervised by Nokia. Hermann (2008) is a talk presented by an employee of PE International, the sustainability consultancy company responsible for producing the $\mathrm{GaBi}$ LCA software. Yu et al. (2010) draws upon a variety of further references for the energy use of mobile phones at each stage of its life cycle. The references by Ercan (2013) and Guvendik (2014) are master's theses reporting on studies carried out in collaboration with the mobile manufacturers Sony Mobile and Fairphone, respectively. It is worth noting that rather than a preference for data produced by the described references, the authors found no explicitly cited references from the following manufacturers: Google (Nexus), Huawei, LG, Motorola, Samsung and ZTE.

It is perhaps not surprising that the majority of studies are published by manufacturers. This can be attributed to the improved access to the relevant data on materials sourcing, manufacture expenditures and transport through the appropriate distribution networks; the kind of information most difficult for external investigators to access. Most often, the disposal of a phone is presented in terms of recycling, rather than disposal through other methods such as reuse, remanufacture or landfill. This is likely to be due to the lack of control that the manufacturer has over the disposal route and the fact that recycling offers the most quantifiable data of all of the best practice disposal methods. The use phase is treated with a similar broad approach, often being described as "typical" in terms of phone use. This is due to the difficulty in defining an all-encompassing user profile, but still leaves little idea of 
what a typical user profile may be. It is often unclear what is considered within scope for inclusion in the user profile, for example, leaving the charger plugged in when not charging. These two life cycle phases will be re-visited later in this article.

Reporting of GHG emissions and energy tend to dominate in articles which are meant for distribution to the general public. The need for simplicity in presentation of information and the wide recognition of these proxies as indication of impact drive their use. However, they cannot represent the true environmental impact of a mobile phone. A more complete set of impact categories are reported in articles by Moberg et al. (2014), Singhal (2005), and Guvendik (2014). Moberg et al. (2014) explore the possibility of simplifying an LCA by various methods, one of which is reduction of the number of categories. The use of a reduced set of categories, e.g. only global warming potential, was not found to be a satisfactory way of summarising impact over multiple life cycle phases. However, it is shown that the majority of the impact occurs within the extraction and manufacturing phases combined, regardless of impact category under consideration. A similar approach to impact category reduction is explored by Gutiérrez et al. (2010), in a study which considers phones as a wider selection of electronic waste. Guvendik (2014), whilst showing a multitude of impact categories, uses global warming potential, human toxicity and metal depletion to highlight the impacts which most closely align with the Fairphone manufacturers' mission. The production phase is shown dominate in the other impact categories, accounting for $99 \%$ of metal depletion and $71 \%$ of human toxicity. Singhal (2005) explores more impact categories relating to a mobile phone made by Nokia in 2003 . However, this life cycle is lacking the end of life phase, due to a cited paucity of data. Frey et al. (2006) report further impacts of mobile phones in terms of ecological footprint. Seppälä and Mattila (2013) use a smartphone as a case study, exploring its impact against a wide range of both environmental and social impact indicators in both the years 2010 and a projected impact in 2030 . Smartphones have even been investigated for the potential offset of impact by the displacement of other devices, such as cameras or laptop (Judl et al. 2012). A further publication has reported the life cycle balance simply in terms of environmental impact (Park et al. 2006). Other studies explore the material inventory of a mobile phone in order to understand their impact. These may be regarding a phones' components (Tan 2005; Yamaguchi et al. 2003; Yang et al. 2004; Sangprasert and Pharino 2013), materials (Lim and Schoenung 2010; Wu et al. 2008; Neira et al. 2006; Osibanjo and Nnorom 2008) or their sustainability (OECD 2010).

Consistency between LCA investigations is key in understanding their wider applicability. It is widely understood within the LCA community that high levels of agreement between studies is hard to achieve due to the complexity of the available data and approximations that must be made. The temporal variability of GHG emissions within individual LCAs when re-assessed using the more up-to-date information in the years 2010, 2011 and 2012 has been explored (Santavaara and Paronen 2013). The variability between different studies has also been explored (Andrae and Andersen 2010), finding that those for mobile phones reporting 100year global warming potentials were nominally more consistent than studies relating to other consumer electronic devices.

\section{Where the impacts of a typical smartphone lie within its life cycle}

In order to explore the implications of extending the scope of the life cycle of a smartphone, it is first illuminating to explore the life cycle profile of such a device. Given the prevalence of GHG emissions above other sources of impact in life cycle reports, it will be the focus for this article. As explored in other articles, GHG emissions are not indicative of the entirety of the environmental impact of smartphone, but for the purposes of this article, it serves as a useful tool to demonstrate the potential changes created by variation in scope.

The data presented is reproduced as reported within the literature without accounting for the possible variations in scope or boundary conditions of the studies referenced. For example, the assumed length of time that the phone is used varies between studies; this is not taken into account at this stage. Although this method is not satisfactory in terms of a greater understanding of the environmental impact of a mobile phone, it reflects how it is sometimes not possible to find the more detailed information behind the declaration. Whilst the lifetime of a phone is always stated, however, information regarding the detailed composition of the components of the phones is not. Even if the relevant information could be found, it would undoubtedly not be to a sufficient detail to allow for an accurate alteration of the data by a third party. Therefore, as a reader of the declarations, sometimes one can only take the information given at face value. Further information, where known, regarding the details behind the data is discussed later. Where possible, the specific phone model is given along with the year of declaration of the results. Where this is not known, the reference to data origin is given. Four life cycle phases are presented: (a) extraction and manufacture (E\&M), (b) transport (trans), (c) use and (d) end of life (EoL). Where studies separate extraction of raw materials and manufacture, or subdivided manufacture into component manufacture and phone assembly, these have been aggregated into one E\&M phase. Where a life cycle phase is missing from a study, attention is drawn to that gap in order to distinguish it from a data value which is very small and therefore may not visible in the graph. Any missing data points are excluded from averaging. 
Table 1 Summarised life cycle data for mobile phones and servers

\begin{tabular}{|c|c|c|c|c|c|c|c|}
\hline Item & Source & $\begin{array}{l}\mathrm{E} \& \mathrm{M} \\
(\mathrm{kg} \\
\mathrm{CO}_{2^{-}} \\
\text {eq })\end{array}$ & $\begin{array}{l}\text { Trans } \\
(\mathrm{kg} \\
\mathrm{CO}_{2^{-}} \\
\text {eq) }\end{array}$ & $\begin{array}{l}\text { Use } \\
(\mathrm{kg} \\
\mathrm{CO}_{2^{-}} \\
\text {eq) }\end{array}$ & $\begin{array}{l}\text { End of } \\
\text { life }(\mathrm{kg} \\
\left.\mathrm{CO}_{2} \text {-eq }\right)\end{array}$ & $\begin{array}{l}\text { Total } \\
(\mathrm{kg} \\
\mathrm{CO}_{2^{-}} \\
\text {eq) }\end{array}$ & $\begin{array}{l}\text { Lifetime } \\
\text { (years) }\end{array}$ \\
\hline \multicolumn{8}{|l|}{ Phones } \\
\hline Nokia, 2003 & $\begin{array}{l}\text { Singhal } \\
(2005)\end{array}$ & 7.9 & 2.1 & 3.6 & & 13.6 & 2 \\
\hline PE International & $\begin{array}{c}\text { Herrmann } \\
\quad(2008)\end{array}$ & 24.5 & 4 & 3.8 & -2 & 30.3 & 4 \\
\hline iPhone $4 \mathrm{~s}$ & $\begin{array}{l}\text { Apple } \\
\text { (2013- } \\
\text { a) }\end{array}$ & 35.75 & 3.85 & 13.75 & 1.65 & 55 & 3 \\
\hline iPhone $5 \mathrm{~s}$ & $\begin{array}{l}\text { Apple } \\
\text { (2013- } \\
\text { b) }\end{array}$ & 56.7 & 3.5 & 8.4 & 1.4 & 70 & 3 \\
\hline iPhone 6 & $\begin{array}{l}\text { Apple } \\
\qquad(2014)\end{array}$ & 80.75 & 2.85 & 10.45 & 0.95 & 95 & 3 \\
\hline HTC One & $\begin{array}{l}\text { HTC } \\
\quad(2013)\end{array}$ & 23.65 & 2.92 & 13.89 & 0.04 & 40.5 & 3 \\
\hline Nokia 105 & $\begin{array}{l}\text { Nokia } \\
\text { (2013- } \\
\text { a) }\end{array}$ & 3.57 & 1.4 & 1.96 & 0.07 & 7 & 3 \\
\hline Nokia Lumia 720 & $\begin{array}{l}\text { Nokia } \\
\qquad(2013- \\
\text { b) }\end{array}$ & 15.12 & 1.89 & 3.78 & 0.21 & 21 & 3 \\
\hline Nokia Lumia 1520 & $\begin{array}{l}\text { Nokia } \\
\text { (2013- } \\
\text { c) }\end{array}$ & 28.86 & 1.85 & 5.92 & 0.37 & 37 & 3 \\
\hline Sony Xperia T & $\begin{array}{l}\text { Ercan } \\
\qquad(2013)\end{array}$ & 35.4 & 5 & 3.8 & 1 & 45.2 & 3 \\
\hline Fairphone & $\begin{array}{c}\text { Guvendik } \\
\text { (2014) }\end{array}$ & 5.34 & 2.73 & 7.91 & 0.07 & 16.04 & 3 \\
\hline \multicolumn{8}{|l|}{ Servers } \\
\hline Dell PowerEdge R710 & $\begin{array}{l}\text { Stutz } \\
\quad \text { et al. } \\
\quad(2012)\end{array}$ & 471 & 15 & 5960 & -86 & 6360 & 4 \\
\hline Various & $\begin{array}{l}\text { Weber } \\
(2012)\end{array}$ & 332 & 37 & 6238 & & 6607 & 6 \\
\hline $\begin{array}{l}\text { Average server data } \\
\text { modified for } 3 \text {-year life- } \\
\text { time and } 1 / 400 \text { original } \\
\text { data }\end{array}$ & & 0.65 & 0.04 & 9.49 & -0.16 & 10.09 & 3 \\
\hline
\end{tabular}

$E \& M$ extraction and manufacturing phase, Trans transport phase
Figure 1 shows the GHG emissions as a function of life cycle phase for various phones from a range of manufacturers and sources (Singhal 2005; Herrmann 2008; Apple 2013a, b, 2014; HTC 2013; Nokia 2013a, b, c; Ercan 2013; Guvendik 2014). The data is shown in Table 1 . The dominant life cycle phase is shown to be the extraction and manufacturing phase in all cases bar one, Guvendik (2014). The reason for this is not immediately apparent, but given that the emissions associated with the Fairphone manufacturing phase are significantly smaller than any other smartphones in the chart $(5.34 \mathrm{~kg}$ $\mathrm{CO}_{2}$-eq compared to $15.12 \mathrm{~kg} \mathrm{CO}_{2}$-eq for the Nokia 720 for example), whereas the use phase is comparable to others, it indicates a choice in the boundary conditions, or assumptions made, for the extraction and manufacturing phase. The answer to some degree may lie in either the fact that they have used commonly available life cycle databases for components or the fact that a Fairphone is shipped without a charger or other ancillary items such as headphones. However, as the declaration for the Nokia handset is also devoid of accessories, packaging, user guides and corporate overheads (Nokia 2015), this is unlikely the root of the difference. Nokia states that this would add approximately $4 \mathrm{~kg} \mathrm{CO}_{2}$-eq to the total. This provides a first indication of the change that choice of scope can have in the reported impact of a mobile phone: the Nokia 105 has a total reported impact of $7 \mathrm{~kg} \mathrm{CO}_{2}$-eq (Nokia 2013a). It is also interesting to note the change between successive 
Fig. 1 Greenhouse gas emissions of mobile phones across life cycle phases: (a) extraction and manufacture (E\&M), (b) transport (trans), (c) use and (d) end of life (EoL)

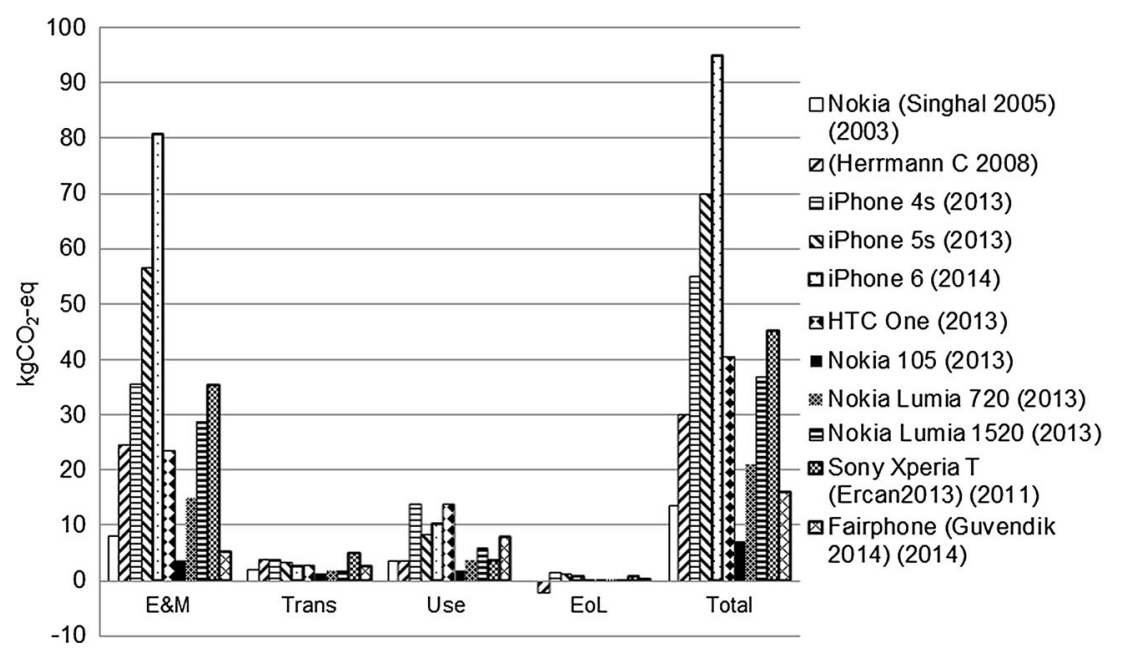

generations of phones from a company. The Apple iPhones consistently show an increasing impact with each successive generation, indicating the rise in complexity of the phones and their GHG emissions. Similarly, the Nokia 105, a purposely simple, modern feature phone, indicates how a simplified handset may lead to reduced impact, compared to the more complex smartphones presented. The end of life is shown to contribute only a small amount to the total overall impact. Indeed, Hermann (2008) reports a negative impact. Such a situation may only arise if offset of the impact of extracting virgin material from the ground is considered. The end of life scenarios represented in the graph are a mixture of landfill and recycling, demonstrating that regardless of disposal method, there is negligible comparable impact arising from this phase.

Figure 2 shows the averaged data for the phones from Fig. 1 which can be considered smartphones, i.e. those with a full front display and manufactured after 2010. This excludes the Nokia 105. The standard error of the mean is shown. The dominance of the extraction and manufacture phase is clear, being $74.1 \%$ of the total impact. The end of life phase is negligible compared to all of the others. This is in part due to the assumptions made surrounding the particulars

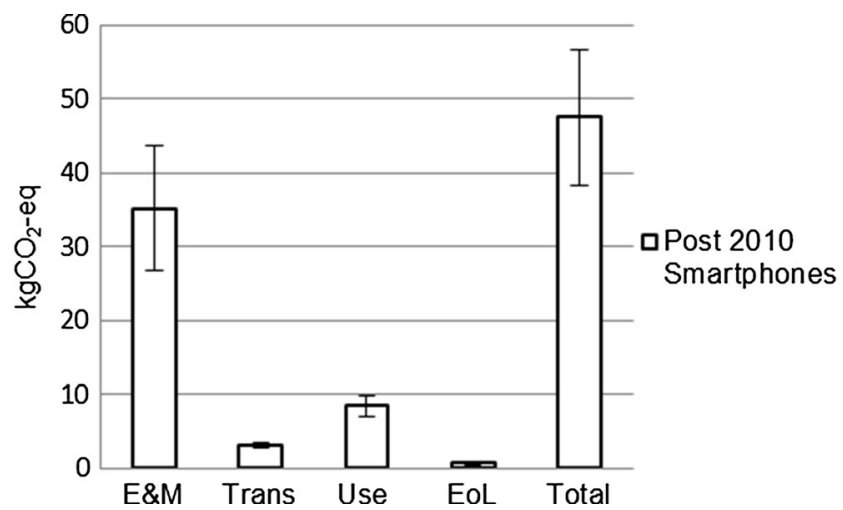

Fig. 2 Averaged life cycle phase distribution for smartphones made after 2010 of disposal: recycling has the potential to make a perceived positive impact on the environment if offset of extraction of virgin raw materials is considered. It should be made clear that the set of LCAs represented in this article is not intended to perfectly reflect the composition of the market in terms of sales volume, or the composition of the ownership base. This is simply not possible given lack of data from many manufacturers, as noted above. In effect, the graph represents the impacts of a typical smartphone as represented in the literature. Having established a base line life cycle for a modern smartphone, the effect of varying the scope can now be explored.

\section{Lifetime of phones}

The use phase of a smartphone is not the most significant in the life cycle, in terms of GHG emissions, but it is one which is wholly dependent on estimate and assumption in order to assess potential impact. For example, the user habits lifetime, its length and defined scope all have an effect. The average lifetime of the data comprising that shown in Fig. 2 is 3 years, as given in all cited reports. However, lifetimes from other studies are often quoted as being shorter (Paiano et al. 2013; Judl et al. 2012; Osibanjo and Nnorom 2008; Wright et al. 1998; Fishbein 2002; Geyer and Blass 2010; Franke et al. 2006; Jang and Kim 2010; Li et al. 2012; Yin et al. 2014; Marukami et al. 2010; Rathore et al. 2011). There is a range of lifetimes presented in some of the articles, portions of which are longer than 3 years, but where a range is given, the average is stated as being less than 3 years and sometimes less than 2 years. There is one exception to the above, Polák and Drápalová (2012), who state 3.63 years for the use by consumers within the Czech Republic. Furthermore, they state a lifetime of exactly 7.99 years if storage time before disposal is included within the definition. Two issues are demonstrated within the above literature. First, the lifetime of phones is 
shorter than anticipated during the design phase and second, their retention for an extended period after initial use reduces their value to any secondary markets, with the associated potential for environmental impact reduction.

\section{User profile}

In addition to the lifetime, the user behaviour can lead to a strong variation of impact. The precise user distribution can never be fully understood and is one of the main sources of estimate within an LCA. Manufacturers' declarations are based upon an assumed typical user (Nokia 2013a, b, c; HTC 2013; Apple 2013a, b, 2014), but the need for brevity prevents further details being given. Academic studies can delve further into the user profile, exploring the effect and contribution of the user base as a whole (Schaefer et al. 2003; Paiano et al. 2013; Judl et al. 2012; Guvendik 2014; Ercan 2013). While these rely on assumption on the part of the investigator, an alternative source of user profile information may be commercially produced marketing reports (Nielsen 2013) or those produced for open source consumption (Pew 2013a; Ericsson 2013). Further studies may be used to identify possible mechanisms for improving energy efficiency of mobile phones by monitoring user behaviour (Falaki et al. 2010).

Aside from the different ways in which data is collected or estimated for user profiles, a common theme between publications is the change in how people use their mobile phones. Schaefer et al. (2003) represents the earliest estimate of a user profile. From the paper, a light user spends $4 \mathrm{~min} /$ day talking with the phone either in standby mode or off for the remainder of time. A heavy user spends $60 \mathrm{~min} /$ day talking and has the phone on for the rest of the time. Crucially, no data transfer is considered. Given the date it most likely considers a feature phone, or one with limited capability. By contrast, Nielsen (2013) use an app installed on a smartphone to collect usage data as a function of the time of day. Summing over the entire day an average smartphone user spends $16 \mathrm{~min} /$ day on voice calls, $18 \mathrm{~min} /$ day gaming, $30 \mathrm{~min} /$ day browsing the internet or on social networks and $15 \mathrm{~min} /$ day on messaging. Including all other activities, a total of $105 \mathrm{~min} /$ day is measured, a rise of $75 \%$ over Schaefer et al.'s heavy user. The data presented herein from the Nielsen report is based on an assumed month length of 30 days. Figure 3 shows a comparison of user profiles from the above and Paiano et al. (2013), as these articles represent ones from which an average user profile can be calculated. All show that the internet is becoming an increasingly important aspect to modern phone usage. Falaki et al. (2010) has not been included in Fig. 3 as activity categories combined voice calls with data connections under the umbrella title of communications, but it also shows an increased and more diverse usage over that given by Schaefer et al. (2003).
The user of a smartphone has been shown to be a heavy user of the internet, through browsing and messaging. But, in addition to the passive consumption of data, for example browsing or watching of videos, smartphone users are increasingly responsible for creation of data. This leads to a legacy of data which must be maintained in order for time delayed access to that same data to be possible, as opposed to the instantaneous creation and consumption of traffic in terms of voice and text facilities of other mobile phones. This can be demonstrated by the increasing presence of internet services which are linked to content generation; social networks such as Twitter, which increased by $28.7 \%$ to $30.8 \mathrm{M}$ users, or $21.3 \%$ of smartphone users within the USA in 2013, or Instagram, increasing by $34.7 \%$ to $34.6 \mathrm{M}$ users, or $23.9 \%$ of smartphone users within the USA (eMarketer 2014). Both services are primarily smartphone based. Similar research shows that of mobile phone users, $20 \%$ use phones to post video online (Pew 2013b), noting that this is a study of mobile users, not just smartphone users, which will result in a dilution of the total percentage. Furthermore, $23 \%$ of adults who post videos online use a mobile app. Uploading a video or image is an obvious, active creation of data, but even using a mobile phone to send e-mail or messages mediated by social media or an online provider will result in data being stored. By this consideration of smartphone usage, the creation of data is intimately within the control of the user, leading to a need to provide the means of supporting the generated data, i.e. the server.

The understanding of user habits and how they are changing over time is key to increasing the useable lifetime of a smartphone through anticipation of likely changes in use trends and designing for those into the system from the outset. The references indicate a change in the use of a mobile phone from a system designed predominantly for voice services, into one which is more an access point to the internet. The trends of data creation and data connections lend future smartphones to the potential of being incorporated into a cloud-based product service system.

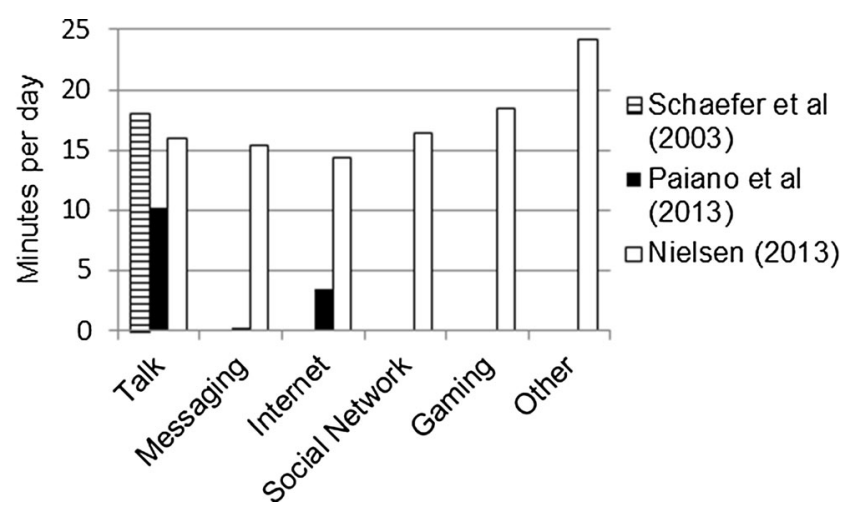

Fig. 3 Usage of mobile phones: estimated data (black, horizontal hashing) and measured data (white) 


\section{Server scope}

The revision of the current business model, i.e. buy-use-discard, to one of a product service system relies on the ability of the service provider to extract value from the provision of the service. Dedrick et al. (2011) explore the value within the supply chain of a mobile phone, showing that the majority of operating profit is extracted by the mobile phone manufacturer and network operator. This shows that there is already a business model providing the service of connecting the phone to a network. Therefore, it is possible that there is also a viable business model in allowing the phone to connect to the world via the internet, as well as the network. If we consider there to be a viable business model in the provision of this service, we can also investigate the potential impacts arising from the service, and where the reductions in impact can be best leveraged.

A sufficient network bandwidth allows the opportunity to create a thin client-based system in which the user accesses a powerful server running a virtual computer through a simple, low power terminal. It has been shown that thin client workstations can reduce GHG emissions by $20-55 \%$ compared to the equivalent number of desktop computers (Andrae 2013). A further, smaller saving was predicted if the thin clients were replaced by tablets. A similar result was reported by Maga et al. (2013). The savings occur by reducing the computing power of the user terminal. This leads to a saving in both manufacture resource consumption, through the use of more simple parts and the associated reduction in manufacture intensity, and a better allocation of available computing power as the full processing power of modern desktop computers is not required by every user all of the time. Although a desktop computer is different to a mobile phone, in terms of the significance of the use phase and the resulting GHG emissions, a cloud-based PSS incorporating a mobile phone must at least consider the server to which the phone is connected as being part of the product system. Judl et al. (2012) and Seppälä and Mattila (2013) estimate the impact of the internet within the life cycle of a mobile phone. However, the treatment of the internet is top down, considering the total energy use of data centres and the total data transfer of mobile devices to arrive at the contribution of the internet to smartphone life cycle. A common functional unit for mobile phones is its use over a specified lifetime, shown to be 3 years for the majority of manufacturers. Given that LCAs of mobile phones tend to focus on the phone in isolation from the network to which it is connected, a start point for the consideration of a cloud PSS technological unit might be the mobile phone and a representative server to which it is tied. It is estimated that for every 400 smartphones, one server is required to support them and their internet use (Bryant 2013). This is not a statement tying the 400 smartphones to one server per se, but a broad indication that the consideration of the net use of a smartphone over the internet will require the total services from many servers equating to approximately $1 / 400$ th of a single server. We can use this as a guide to estimate the additional impact that a server may cause.

Two studies are found which relate to the type of server which may relate to a cloud PSS, which may be those found in a data centre. They report total GHG emissions of $6360 \mathrm{~kg}$ $\mathrm{CO}_{2}$-eq for a Dell PowerEdge R710 (Stutz et al. 2012), assuming use in the US and associated electricity grid mix, and a mean of $6607 \mathrm{~kg} \mathrm{CO}_{2}$-eq (Weber 2012) over the lifetime of a study looking at the variation in life cycle GHG emissions from servers. Weber (2012) used regional electricity mixes. This article uses the mean data as presented in the paper. To put this in context, the averaged total GHG emission of the smartphones represented in Fig. 2 is $47.5 \mathrm{~kg} \mathrm{CO}_{2}$-eq. Taking the average of the total GHG emissions from the studies by Weber (2012) and Stutz et al. (2012) to be $6484 \mathrm{~kg} \mathrm{CO}_{2}$-eq, the average emission relating to a smartphone equates to approximately $1 / 140$ of this. This is significantly larger than the 1/400 estimated by Bryant (2013). However, this comparison is made over the entire life cycle of both the smartphone and server. The distribution of impact throughout the life cycle differs significantly between the two devices. The main environmental impact of a smartphone in terms of GHG emissions is in the manufacture phase, whereas the server creates greatest environmental impact during the use phase. Both Stutz et al. (2012) and Weber (2012) reports $94 \%$ of all GHG emissions attributed to the use phase. By comparison, the use phase of a smartphone accounts for less than $18 \%$ of the total GHG emissions of the life cycle. With this in mind, Fig. 4 shows the impacts of 1/400th of a server's GHG emissions overlaid onto the life cycle of a smartphone. The total impact is balanced to the average lifetime of a smartphone as given in the literature by normalisation to the cited lifetime within each server article. For reference, these values are reproduced in Table 1. The use phase shows a split of contribution of $9.5 \mathrm{~kg} \mathrm{CO}_{2}$-eq from the server compared to $8.5 \mathrm{~kg}$ $\mathrm{CO}_{2}$-eq from the smartphone, an increase of $112 \%$. In terms

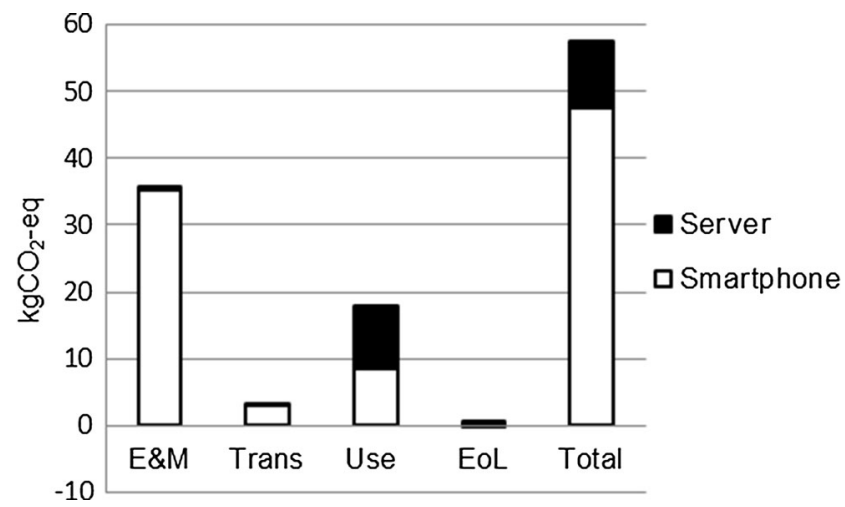

Fig. 4 GHG emissions across the life cycle of a smartphone (white) including contribution from a rack server (black) 
of the whole life cycle, the server adds $10.1 \mathrm{~kg} \mathrm{CO}_{2}$-eq of GHG emissions, an additional $21 \%$ over the $47.5 \mathrm{~kg} \mathrm{CO}_{2^{-}}$ eq of a smartphone. The impact of the server upon the other life cycle phases is small.

\section{Network scope}

The life cycle profile presented in Fig. 4 may be considered to represent that of a product system as designed by the service provider. To that extent, it is analogous to the environmental product declarations as published for phones at the present, i.e. it covers all of the items which would be necessary to provide the function as sold by the manufacturer to the user. It ignores the impact caused by purchase of the service from another company, i.e. the network provider. As it may be argued that a network is necessary for the operation of a mobile phone, this section will explore the effect that including the network could have upon the life cycle. The life cycle of networks has been studied in isolation (Malmodin et al. 2001; Emmenegger et al. 2006). Further studies have explored the decommissioning of the network infrastructure (Scharnhorst et al. 2006; Scharnhorst 2005), specifically the transition from GSM $(2 \mathrm{G})$ to UMTS $(3 \mathrm{G})$ networks and how the transition time between the two should be minimised to avoid unnecessary environmental burden. Articles by Schaefer et al. (2003), Yu et al. (2010), Ercan (2013) and Malmodin et al. (2010) provide an estimate of the energy use per user for various mobile networks. The values presented are derived from a mixture of top down and bottom up approaches allocating users a fraction of total network energy consumption. The network energy consumption is either calculated by summation of individual component power ratings over time or by studying the energy consumption of the network providers. Emmenegger et al. (2006) provide information on the energy use to download a specified amount of data. Again, this is based upon total network energy consumption and data transfer. It is estimated that in 2018 each smartphone will transfer 1.9 GB per month in data traffic compared to 1 GB per month in 2015 (Ericsson 2013). Further studies have explored the life cycle of $2 \mathrm{G}$ compared to $3 \mathrm{G}$ mobile networks in terms of a multitude of impact categories (Scharnhorst et al. 2006). In order to investigate the potential impact that the network may contribute to a smartphone, the energy consumption given as $\mathrm{kWh}$ per subscriber, must be converted to $\mathrm{kgCO}_{2}$-eq. This will be discussed on a case by case basis.

Malmodin et al. (2010) state the energy per year per subscriber as $16 \mathrm{kWh} / \mathrm{subscriber}$ (subs)/year. Using the global conversion for electricity provision of $0.6 \mathrm{~kg} \mathrm{CO} \mathrm{CO}_{2}$-eq/ $\mathrm{kWh}$ as given in the article yields a global warming potential (GWP) of $9.6 \mathrm{~kg} \mathrm{CO}$-eq/subs/year. This value is based upon the reported electricity consumption of multiple mobile operators and their subscriber base. Although the article goes further to include the operator activities and supplementary generation of electricity by diesel generator, this will not be considered in this article, to allow comparison to the others referenced. The choice of per subs or per phone is dependent on the target of the calculation in the referenced article, but essentially amounts to the same individual unit of one person using one phone. Schaefer et al. (2003) give an energy consumption of $15 \mathrm{kWh} / \mathrm{subs} /$ year. This is based upon the summation of the total energy consumption and the multiple individual components that make up the mobile network in Germany. These are the base transceiver stations, base station controllers and mobile service switching centres, with given power ratings of 1100, 475 and $4000 \mathrm{~W}$, respectively, multiplied by the total number of each (Schaefer et al. 2003). The total energy consumption in a year is divided by the number of subscribers in Germany in 2003, 44.8M. Finally, Yu et al. (2010) provide an energy consumption of $9.1 \mathrm{kWh} / \mathrm{subs} / \mathrm{year}$. The calculation is the same as Schaefer et al. (2003), but with data taken from China regarding infrastructure and subscriber quantity. A summary of the referenced data is shown in Table 2. The key difference between the latter two is the number of subscribers on a given network infrastructure, a number which is dependent on population density within a service coverage region or efficiency of use of the network. Assuming that the energy consumption for the network is entirely grid electricity, a simplification necessary out of lack of available information of the supplementary operations or energy supply to the network, conversion factors for electrical energy to global warming potential is required. Using the International Energy Agency (IEA) (2013) conversion factors for the year of the network under study, $0.526 \mathrm{~kg} \mathrm{CO}$-eq/kWh for Germany (2000) and $0.797 \mathrm{~kg} \mathrm{CO}$-eq/kWh for China (2008), we can estimate GHG emissions equivalent to $7.9 \mathrm{~kg} \mathrm{CO}$-eq/subs/year and $7.2 \mathrm{~kg} \mathrm{CO}$-eq/subs/year for Schaefer et al. (2003) and $\mathrm{Yu}$ et al. (2010), respectively. This data is also summarised in Table 2. Figure 5 shows the effect of this upon the life cycle profile of the smartphone (dotted bar). Taking the average of the three values from Schaefer et al. (2003), Yu et al. (2010) and Malmodin (2010) and scaling up to the 3-year lifetime of the mobile phone, the contribution of the network can be estimated to be $24.7 \mathrm{~kg} \mathrm{CO}_{2}$-eq/sub, substantially more than the $8.5 \mathrm{~kg} \mathrm{CO}_{2}$-eq of the phone. This is now the most significant contributor to use phase GWP. Malmodin et al. (2010) also give a value of $3 \mathrm{~kg} \mathrm{CO}_{2}$-eq/ subs for the manufacture of the network. Given that the network itself tends to have a longer lifetime than the mobile phones attached to it, this contribution is small. But, even if we assume that it is 3 years, the impact at the manufacturing stage is only $3 \mathrm{~kg} \mathrm{CO}$-eq/subs and far smaller than the $35.2 \mathrm{~kg} \mathrm{CO}_{2}$-eq calculated for the average smartphone. 
Table 2 Summarised life cycle data for networks and conversion factors

\begin{tabular}{lllll}
\hline Annual figures & $\begin{array}{l}\text { Power } \\
(\mathrm{W})\end{array}$ & $\begin{array}{l}\text { Schaefer (2003) } \\
\text { Data year: 2000 }\end{array}$ & $\begin{array}{l}\text { Yu (2010) } \\
\text { Data year: 2008 }\end{array}$ & $\begin{array}{l}\text { Malmodin (2010) } \\
\text { Data year: 2007 }\end{array}$ \\
\hline Base transceiver station & 1100 & 67,700 & 585,000 & \\
Base station controller & 475 & 1198 & 5850 & \\
Mobile service switching centre & 4000 & 575 & 2925 & \\
Total energy (GWh) & & 678 & 5763 & 16 \\
Number subs (millions) & & 44.8 & 634 & 0.6 \\
Energy per subs (kWh/subs) & & 15 & 9.1 & 9.6 \\
Conversion factor (kg CO 2 -eq/kWh) & & 0.526 & 0.797 & 7.2 \\
Per user (kg CO -eq/subs/year) & 7.9 & 7.2 & \\
\hline
\end{tabular}

Equation for total network energy used by Schaefer et al (2003) and Yu et al (2010): Electrical energy [Wh per year] $=$ average power consumption ${ }_{X Y Z}[\mathrm{~W}] \times 8760\left[\mathrm{~h}\right.$ per year] $\times$ stock $_{X Y Z}[$ no.]
The contribution from the IP core network has been discussed by Malmodin et al. (2012) and Ercan (2013). This is defined as the portion of a data network that sits between the data centres and in the case of mobile phones, the mobile radio network. It is calculated that $3 \mathrm{G}$ mobile users generate between 8.5 and $30 \mathrm{~GB} /$ year in data which is transmitted across the IP core network. This corresponds to 0.55 to $2 \mathrm{~kg} \mathrm{CO}_{2}$-eq/ year, respectively, as calculated in the reference using a global grid mix of electricity $\left(0.6 \mathrm{~kg} \mathrm{CO}_{2}\right.$-eq $\left./ \mathrm{kWh}\right)$. The allocation of impact is based upon the proportion of mobile data as a subset of all data traffic (3.4\%). It should be noted that the figures cited also include an allocation per GB of cable deployment and manufacture of required IT equipment and the end of life phases of those two items. The impact of equipment will continually decrease over time as it is replaced with more efficient hardware. The use phase accounts for approximately $0.05 \mathrm{~kg}$ $\mathrm{CO}_{2}$-eq/GB and the manufacture, cable deployment and end of life phases $0.014 \mathrm{~kg} \mathrm{CO}$-eq/GB. If we assume that the upper bound of $30 \mathrm{~GB} /$ year represents the data transfer of a cloud-based system, we can estimate that the impact over the 3-year lifetime of a smartphone is approximately $4.5 \mathrm{~kg} \mathrm{CO}_{2}$ eq in use and $1.3 \mathrm{~kg} \mathrm{CO}_{2}$-eq in manufacturing and deployment for the IP core network (assuming that the end of life impact is

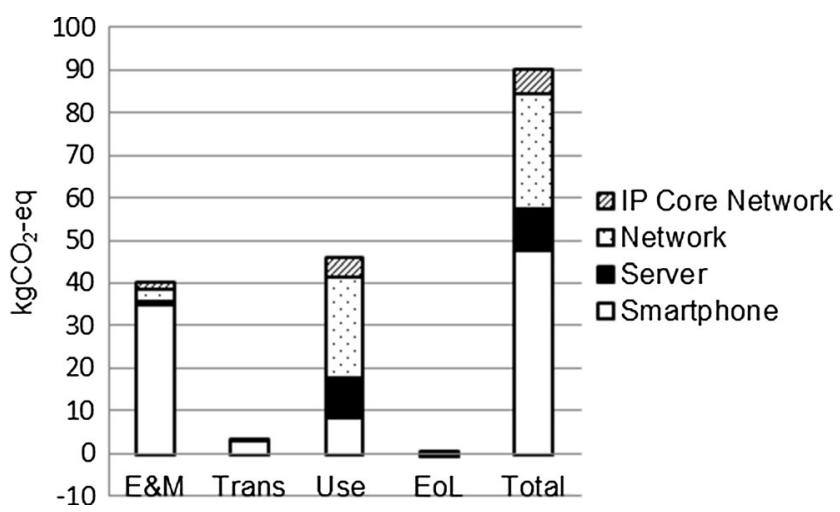

Fig. 5 GHG emissions across the life cycle of a smartphone (white) including contribution from a rack server (black), network (dots) and IP core network (diagonal hashing) negligible as demonstrated in the other LCAs discussed). The contribution of this estimate is also added to Fig. 5 (diagonal hashing). Based upon the estimate presented here, it is potentially the smallest contributor to impact, but one which may vary significantly depending on true data quantity generated or downloaded to and from the phone used within a cloudbased PSS.

The data as presented in this article demonstrates a significant set of variables in calculating impact of mobile phone and network use. First, the networks represent a range of ages from pre-2003 to 2010 . Therefore, a mix of $2 \mathrm{G}$ and $3 \mathrm{G}$ is represented. Given the varying rate of roll out of mobile network technologies across the world, this mix will be difficult to quantify on a global scale. Particularly as the mix of infrastructure, making up the network will have varying ages in any given year in any given region. This leads to the second point; the location upon which the network calculation is made varies considerably, itself important for two reasons. One, the subscriber density on a network is shown to make a significant change in the energy consumption per user as exemplified by Schaefer et al. (2003) and Yu et al. (2010). And two, the conversion of energy consumption to GHG emissions is highly dependent upon the mix of grid electricity. All of these factors act to make it difficult to get a true indication of the change of network environmental impact over time. Regardless, the dominance of the network in the life cycle profile is not reduced by removal of the older references as Malmodin et al. (2010) represents the greatest impact (see Table 2). This is further exacerbated by the lack of $4 \mathrm{G}$ data at present, which would surely represent the minimum network technological level for a proposed cloud PSS.

\section{Charger specification}

When consulting product declarations, it is not often clear if the charger is included in the LCA or not. The summarised declarations often do not give sufficient information to make 
an informed decision as to the items considered within scope. For example, Apple state that packaging is included, but not if accessories are. Nokia do not state what is included in the declaration, the website must be consulted in order to find out that accessories are not included, but may add a potential $4 \mathrm{~kg} \mathrm{CO}$-eq to the phone total. Similarly, information on whether the charger standby is included within the use phase is often missing. What are the implications upon the life cycle if the charger is either included or excluded? Like many aspects of LCA, timeliness of charger use data is important for an accurate estimate of impact. For example, Schaefer et al. (2003) quotes a standby charger energy consumption of $1.5 \mathrm{~W}$. Given that they assume that the charger is in use for $3 \mathrm{~h}$ a day and then on standby for the rest of the time, this equates to approximately $12.9 \mathrm{kWh} /$ year, on a par with the $15 \mathrm{kWh} /$ year quoted in the same article for network energy consumption. In more recent years, chargers have shown a remarkable reduction in energy consumption. Apple (2013a) shows a standby drain of $0.25 \mathrm{~W}$ at $230 \mathrm{~V}$ for available reports up to 2013 for the iPhone 4s. Interestingly, a report published on the same date but for the iPhone 5 (Apple 2013b) reports a consumption of $0.011 \mathrm{~W}$, a reduction of over a factor of 20. Although not explicitly stated as being considered within the use phase, the drop in energy consumption observed between the iPhone $4 \mathrm{~s}$ and $5 \mathrm{~s}$ in Fig. 1 might be attributable to such a reduction of the charger standby power. Nokia (2013a, b, c), Ercan (2013) and Guvendik (2014) similarly report charger standby drain of $0.03 \mathrm{~W}$ or less. Guvendik (2014) is one of the few who explicitly states the assumptions surrounding the consideration of charger use in the use phase. Over 3 years, charging of the smartphone is shown to require $11.8 \mathrm{kWh}$, whereas the charger standby is shown to be only $0.26 \mathrm{kWh}$. This is based upon different users leaving the charger on for an average of $33.5 \%$ of the time. Therefore, the charger contributes only $2.2 \%$ of the phone energy consumption. Exploring this further, the Apple charger value of $0.011 \mathrm{~W}$, under the same circumstances would contribute only $0.1 \mathrm{kWh}(0.8 \%)$ to the net use, whereas Schaefer's value of $1.5 \mathrm{~W}$ would contribute $13 \mathrm{kWh}$ to net use. It can be seen that as modern mobile phones replace the older ones, the energy demand globally will reduce significantly. In the case of Guvendik (2014), the charger in question is an optional one which can be purchased by the consumer; Fairphone do not supply a charger by default, citing that many users often have USB charging capability already available to them and do not require the extra, redundant accessory. This opens up an interesting question as to the allocation of charging resource for future consideration of mobile phone impact, or the benefits of universal chargers (Cucchietti et al. 2011). In any case, the impact associated with the charger in the future will only diminish as they become ever more efficient in standby.

\section{End of life}

On first appearance, the most significant area to make savings is in the energy consumption and associated GHG emissions of the networks, servers and phones themselves in the use phase. The energy savings possible from the simplification of the mobile phone with associated manufacturing savings and longer lifetime through reduced rate of obsolescence of the parts become less significant to the reduction of impact in general. However, this only considers global warming or energy use and its importance to environmental impact. Moberg et al. (2014) show that the majority of impact of a mobile phone occurs at the production phase for every impact category aside from ozone layer depletion potential which is shown to be greatest during the materials process phase. As these two phases are combined in this article, the E\&M phase dominates every impact category. In contrast to servers and networks, the disposal of mobile phones is often less than ideal, as will be demonstrated in this section. This is an area which is not typically highlighted in product declarations, with their emphasis on recycling and GHG emissions. The loss of components and materials creates an unnecessary burden, one which could be reduced with an appropriate incentive to collect the old phones at end of life. The introduction of a cloud-based PSS, which would incorporate an effective means of take-back at end of life, is an area in which great influence can be exerted over environmental impact reduction. Guvendik (2014) demonstrated that $99 \%$ of the metal depletion occurred at the E\&M phase. This may be most acutely observed in the use of indium within the LCD of the phone. It is estimated that around $80 \%$ of all indium is used within the indium-tim-oxide conductive coating in LCDs (Polinares 2012). Therefore, in order to address this loss of material, the recapture of redundant mobile phones at end of life becomes critical.

\subsection{End of life disposal}

The end of life disposal of mobile phones does not often follow the recycling route assumed in manufacturers' declarations, due to variations in human behaviour and is therefore a rich area for further studies. These include surveys of consumers' willingness to partake in, or pay towards, recycling (Nnorom et al. 2009; Ongondo and Williams 2011a; Yin et al. 2014; Polák and Drápalová 2012; Yang 2008; Jang and Kim 2010). As may be expected, these studies are highly dependent on regional and sociological factors, with the referenced studies being mainly relevant to the UK, China, Nigeria, Korea and the Czech Republic. Recycling of phones is only as effective as public awareness of the importance of doing so. The above studies highlight a lack of return of phones with many being stockpiled by consumers for varying reasons, including keeping the old phone in case of breakdown of the 
new one. By way of example, Polák and Drápalová (2012) show that only $3-6 \%$ of old phones were returned in 2010 for recovery or recycling in the Czech Republic. A similar value of $5 \%$ is reported by Buchert et al. (2012) for Germany and other low values from around the world (Tanskanen 2013; Chancerel 2009). One major route for mobile phone end of life is stockpiling, with 3.7 million phones stockpiled by 2.4 million higher education students in the UK (Ongondo and Williams 2011a). Regardless of geographical location, stockpiling of phones is a major route for disposal (Fairphone 2014; Tanskanen 2013; OECD 2010; Rathore et al. 2011). The disposal route after the stockpiling period was not reported. Phones sold or donated can often make their way to lower value markets in developing countries, where responsible return becomes more difficult due to lack of infrastructure (Inform 2003; Osibanjo and Nnorom 2008). Reuse of phones is cited as an effective way of reducing the impact of mobile phones, the enablers and restrictions to this is explored for people living in Germany, Japan, the USA and Canada (Huang et al. 2009).

While the main reason for replacing a mobile phone may be the appearance of a newer, better specified one (Rathore et al. 2011), another significant reason is the damage caused to an old one. The benefits of repairing a mobile phone over replacing it have been explored, with findings in favour of repair where possible (Legarth et al. 2003; Yang 2008).

\subsection{Take-back schemes}

Encouraging return of the mobile phones at end of life is a priority for recovery of any of the phones, their components or the materials used within them. Studies investigate the effectiveness of different end of life schemes (Wright et al. 1998; Osibanjo and Nnorom 2008; Ongondo and Williams 2011b; Fishbein 2002; Ponce-Cueto et al. 2010; Silveira and Chang 2010). The management of take-back reverse logistics may be explored (Jayant 2014). The use of agent based modelling to explore the potential for creating a closed loop system for mobile phones has been reported (Bollinger et al. 2011). Regardless of the take-back scheme in operation, it has been found that their effectiveness is limited by the awareness of the consumer of the need to recycle old devices (Wright et al. 1998; Canning 2006; Milovantseva and Saphores 2013).

\subsection{Reuse and remanufacture}

Moberg et al. (2014) reported the impact of mobile phones in terms of the component parts. The integrated circuits were shown to contribute a significant proportion of the overall impact across multiple categories. Coupled with their high rate of development, this highlights the need to recover these in good time and avoid stockpiling. This is demonstrated by Geyer et al. (2008) in the calculation of reduced total energy consumption by using a low power, $1-\mathrm{W}$ processor for 10 years, compared to upgrading to more efficient ones every 2 years. This is even without considering the resources used in making a new chip (Williams et al. 2002). Corroboration of this is given by Frey et al. (2006) who show that, even with a $20 \%$ improvement in phone efficiency every 4 years, after 10 years, it is more sustainable to keep using the old phone.

Remanufacture of mobile phones is found to result in an improved eco-efficiency compared to purchase of new ones (Quariguasi-Frota-Neto and Bloemhof 2012). This study included considerations such as willingness to pay and cumulative energy demand in determination of eco-efficiency. The potential acceptance of remanufactured mobile phones in India has been explored, with generally positive results, as a means of improving sustainability of the market there (Rathore et al. 2011). The option of repurposing of smartphones into a different role has also been shown to reduce impact across multiple impact categories, even compared to refurbishing (Zink et al. 2014).

The reuse and remanufacture of phones should not be judged solely on environmental impact. The economics of recycling mobile phones have also been explored (Chancerel 2009; Geyer and Blass 2010; Neira et al. 2006; Bhuie et al. 2004; Takahashi et al. 2009). In particular, it is shown that the reuse market is the major source of economic gain at present. In contrast, recycling of phones is shown not to be economically viable as a stand-alone business, the reverse logistics eating away at the profit margin: the collection of mobile phones for recycling is almost entirely subsidised by the collection for reuse and their being a by-product of this industry (Geyer and Blass 2010). Planning of the remanufacturing process is necessary to extract the best benefit (Franke et al. 2006). Improved mechanisms for return of mobile phones within a short period of time after their use phase will lead to improved rates of reuse and remanufacture.

\subsection{Recycling}

Recycling is a third option, especially if phones have been subject to a lengthy hibernation. This may be either to extract value from the metals or to prevent potential environmental damage from release of harmful substances. Mobile phones require a multitude of materials during their construction and can contain more than 40 elements (UNEP 2009; OECD 2010), many of which are considered as being at high risk (BGS 2012). A multitude of studies have explored the material composition of mobile phones by weight (Bhuie et al. 2004; Hageluken 2006; Huisman 2004; Navazo et al. 2014; Tanskanen 2013; Wu et al. 2008; Yu et al. 2010), or their printed circuit boards (PCBs) (Kasper et al. 2011; Wang and Gaustad 2012; Yamane et al. 2011), or simply elemental content (Takahashi et al. 2009). One in particular investigated the potential for recovery of copper from PCBs (Kasper et al. 
2011). The value in recovery of metals from waste circuit boards can be stated as a priority list incorporating multiple drivers, i.e. monetary value, energy saving potential and toxicity potential (Wang and Gaustad 2012). It is generally shown that a minority of the elements found within a phone make the majority of money from recycling. For example, gold, palladium, silver and copper, are shown to make up $~ 99 \%$ of the recycled value, despite only being $13.2 \%$ of the content of a phone (Yu et al. 2010). Interestingly, the fraction of gold, although tiny at $0.04 \%$ by weight, is still approximately 200 times greater than that found in a South African gold mine (Takahashi et al. 2009). This leads to consideration of waste electrical and electronic equipment as a resource to be mined (Oguchi et al. 2011), a viewpoint which may become increasingly important as resource scarcity becomes more acute in the future. The quantity of valuable materials from mobile phones is dependent on the recycling method, with the recommendation that mobile phones are treated separately to other e-waste due to their highly complex construction (Hageluken 2006; Huisman 2004). The physical properties of recycled materials from mobile phones have also been studied with emphasis on the polymers (Monteiro et al. 2007).

Aside from economic gains, the incentive to recycle mobile phones can come from preventing release of toxic substances into the environment by poor disposal practices. Mobile phones have been studied for their potential toxicity due to the metals present (Wu et al. 2008; Bhuie et al. 2004; Lim and Schoenung 2010). The toxicity need not be limited to the metals, other materials are also responsible for adverse effects (Fishbein 2002). Disposal of mobile phones into landfill is a real possibility under the current business model which can result in leaching these materials and metals into the environment (Kiddee et al. 2013; Lincoln et al. 2007; Uryu et al. 2003). The location of recycling will have an effect upon its eventual environmental impact (Soo and Doolan 2014; Wong et al. 2007; Rochat et al. 2007), and it is shown that governmental legislation plays an important role in the controls placed upon emissions. The emissions associated with pyrolysis of mobile phones have been analysed (Molto et al. 2011) along with open air burning of e-waste (Nnorom and Osibanjo 2009; Gullett et al. 2007).

The GWP associated with the metals within a mobile phone have been shown (Ercan 2013), in which it was demonstrated that gold contributed the most, approximately $0.24 \mathrm{~kg} \mathrm{CO}_{2}$-eq, compared to the other main metals, copper, steel, silver and aluminium (the next most significant at approximately $0.12 \mathrm{~kg} \mathrm{CO}_{2}$-eq). For comparison, the GWP per gram is given in the same article as being $19 \mathrm{~kg} \mathrm{CO}_{2}$-eq/g for gold and $0.011 \mathrm{~kg} \mathrm{CO}_{2}$-eq for aluminium. From the perspective of energy saving and hence GHG emission reduction, the recycling of metals from mobile phones results in a saving over extracting virgin metal of up to $50 \%$ (Navazo et al. 2014). This is especially true for the metals which have been shown to currently represent the most value in the phone: copper, silver, gold and the platinum group metals. It is generally beneficial to recycle phones, even when considering the energy used in the take back scheme (McLaren et al. 1999). The end of life disposal of mobile phones has multiple highlighted problem areas. Improved provision of take-back schemes and the awareness of them are necessary to prevent leakage of materials form a closed loop system, ensure their recapture and reduce release of toxic materials into the environment at true end of life disposal. Reducing stockpiling of old handsets and ensuring a timely recovery will best enable the reuse and remanufacture of the components or the whole phone, bringing associated savings from reduced need to produce replacement components from raw materials. A product service system based around a cloud has the potential to provide solutions to these issues.

\section{Conclusions}

The goal of this paper was to understand the literature surrounding the impact of mobile phones upon the environment and to explore the scope of what might be included with respect to the provision of a proposed cloud based PSS business model. The aim of such a model is to reduce the environmental impact of mobile phones by outsourcing, amongst other things, the heavy processing power and large memory storage from the handset itself to a remote computer connected to it by a network. Such systems have been shown to reduce the environmental impact of desktop computing, and it is proposed that one might also do the same for mobile telephony. However, in order to understand the potential savings, or pitfalls, to such an approach, the scope of the life cycle of a mobile phone has been explored to identify what changes occur. First, the profile of a typical phone has been presented in terms of GHG emissions. It is shown that the majority of the impact occurs at the $\mathrm{E} \& \mathrm{M}$ phase and that the use phase is about a four times smaller. The typical functional unit of a mobile phone LCA is its production and use for 3 years. This consists of the product as sold to the consumer and excludes the extra network services they purchase. Therefore, it is proposed that a cloudbased PSS should consist of at least the handset and the server to which it is connected. It is shown that in terms of GHG emissions, the use phase would be subject to a doubling of impact, whereas the other phases would not show significant change. Charging habits of users has been shown to be an ever decreasing part of the life cycle, with modern chargers contributing $2 \%$ or less of total use impact. Given the reliance upon the network of a cloud-based system, this has been explored to give an indication of the potential impact. It is shown that the network is the biggest contributor to this phase. The discussion of charger habits and network impacts also highlighted the timeliness, geography and GHG emission 
calculation and difficulties that this may cause in interpreting data from studies spread over a wide range of dates. The mobile phone industry is a rapidly changing market in developed and developing countries. The effects that this has on interpretation of data must be born in mind. Detailed analysis based upon the locality of the mobile phone and network would be required. However, although awareness of the contribution of the network is important to understanding the potential impact which the cloud-based PSS may cause, it is in contravention to the current practice of only declaring the impacts associated with the hardware as sold to the consumer. Finally, the impact associated with the component and materials of the phones have been explored.

The reuse or remanufacture of phones and parts is key to reducing environmental impact through the lessened requirement to make new ones. It has been shown that extraction of value from each of them at end of life requires the timely return of phones through effective take-back schemes, something currently lacking due to the reliance upon the consumer to drive the process. A mobile handset supported by a cloudbased PSS has the opportunity to improve the end of life environmental impact by increasing business incentive for prompt recovery of old handsets from users. Not only will this reduce the environmental impact of the manufacturing stage of subsequent handsets but also reduce the impact associated with inappropriate disposal. However, although the PSS could offer benefits, there is more investigation required in order to understand the true savings. For example, what are the true impacts of transferring the reliance of computational power away from the handset to a remote computer and are there really potential savings from simplification of the handset? In addition, creation of such a system will require a vastly improved mobile network infrastructure over that currently existing, with improved bandwidth across the entire area of any given country. Finally, the consumer acceptance of the PSS is an area of on-going investigation. Whilst the idea of sharing data via social media and the use of e-mail servers for communications is not new, the term cloud is and still awaiting general acceptance by consumers. This attitude is not least driven by uncertainty over who owns the data stored in the cloud (BBC 2014a) and questions currently unanswered about security (BBC 2014b). Both of these issues must be addressed before such a PSS can be widely accepted. Further investigation is required to ensure that the adoption of a cloudbased PSS not only offers a reduced environmental impact from the perspective of the mobile handset but also avoids burden shifting to the hidden parts of the service, namely the server.

Acknowledgments The authors wish to thank the Engineering and Physical Sciences Research Council (EPSRC) for their financial support of this work as part of the Closed Loop Emotionally Valuable E-waste Recovery (CLEVER) project.

\section{Compliance with ethical standards}

Funding The work presented in this article is funded by the EPSRC (grant number EP/K026380/1). The authors confirm that data underlying the findings are available without restriction. Details of the data and how to request access are available from the University of Surrey publications repository: http://epubs.surrey.ac.uk/807454/.

Conflict of interest The authors declare that, other than the funding by the EPSRC, they are not aware of any other potential conflicts of interest. The authors confirm that there were no human participants, or animals, used in the research presented.

Open Access This article is distributed under the terms of the Creative Commons Attribution 4.0 International License (http:// creativecommons.org/licenses/by/4.0/), which permits unrestricted use, distribution, and reproduction in any medium, provided you give appropriate credit to the original author(s) and the source, provide a link to the Creative Commons license, and indicate if changes were made.

\section{References}

Abolfazli S, Sanaei Z, Ahmed E, Gani A, Buyya R (2013) Cloud-based augmentation for mobile devices: motivation, taxonomies and open challenges. IEEE Commun Surv Tutor 16(1):337-368

Andrae ASG (2013) Comparative micro life cycle assessment of physical and virtual desktops in a cloud computing network with consequential, efficiency and rebound considerations. J Green Eng 3:193-218

Andrae ASG, Andersen O (2010) Life cycle assessments of consumer electronics - are they consistent? Int J Life Cycle Assess 15:827836

Apple (2013a) iPhone 4s Environmental Report. Apple website. http:// images.apple.com/environment/reports/docs/iPhone 4 s_product environmental_report_sept2013.pdf. Accessed 29 May 2014

Apple (2013b) iPhone 5 Environmental Report. Apple website.http:// images.apple.com/environment/reports/docs/iPhone5s_product environmental_report sept2013.pdf. Accessed 29 May 2014

Apple (2014) iPhone 6 Environmental Report. Apple website.https:// www.apple.com/euro/environment/reports/docs/ iPhone6_PER_Sept2014.pdf Accessed 2 February 2015

BBC (2014a) British Broadcasting Corporation news report: Microsoft ordered to hand over emails on Dublin server. http://www.bbc.co.uk/ news/technology-28601788. Accessed 16th February 2015

BBC (2014b) News report: FBI investigates 'Cloud' celebrity picture leaks. http://www.bbc.co.uk/news/technology-29011850 Accesses 16 February 2015

Beuren FH, Ferreira MGG, Miguel PAC (2013) Product-service systems: a literature review on integrated products and services. J Clean Prod 47:222-231

BGS (2012) British Geological Survey: Risk List 2012. http:// www.bgs.ac.uk/mineralsuk/statistics/riskList.html Accessed: August 2014

Bhuie AK, Ogunseitan OA, Saphores J-DM (2004) Shapiro AA (2004) Environmental and economic trade-offs in consumer electronic products recycling: a case study of cell phones and computers. IEEE Int Symp Electron Environ. doi:10.1109/ISEE.2004.1299691

Bollinger LA, Davis C, Nikolić I, Dijkema GPJ (2011) Modelling metal flow systems: agents vs equations. J Ind Ecolog 16:176-190

Bryant D (2013) Accelerating the data centre transformation. http://www. htc.com/assets-desktop/images/csr/tw/download/HTC-One-CFPreport.pdf. Accessed 29 May 2014

Buchert M, Manhart A, Bleher D, Pingel D (2012) Recycling critical raw materials from waste electronic Equipment. Report by Oko- 
Institute. V. Institute for Applied Ecology.http://www.oeko.de/ oekodoc/1375/2012-010-en.pdf. Accessed 2 Feb 2015

Canning L (2006) Rethinking market connections: mobile phone recovery, reuse and recycling in the UK. J Bus Ind Mark 21(5):320-329

Chancerel P (2009) Rotter VS (2009) Assessing the management of small waste electrical and electronic equipment through substance flow analysis - the example of gold in Germany and the USA. IEEE Int Symp Sustain Syst Technol. doi:10.1109/ISSST.2009.5156718

Cucchietti F, Giacomello L, Griffa G, Vaccarone P, Tecchio P, Bolla R, Bruschi R, D'Agostino L (2011) Environmental benefits of a Universal Mobile Charger and Energy-Aware Survey on Current Products. IEEE IntTelecommun Energy Conf (INTELEC), p1-9. Doi: 10.1109/INTLEC.2011.6099888 DOI:10.1109/INTLEC. 2011.6099888

Dedrick J, Kraemer KL, Linden G (2011) The distribution of value in the mobile phone supply chain. Telecommun Policy 35:505-521

eMarketer (2014) Instagram usage in the US surges 35\% in 2013, rivals Twitter for smartphone audience. http://www.emarketer.com/ Article/Instagram-Usage-US-Surges-3537-2013-Rivals-TwitterSmartphone-Audience/1010713. Accesses 30 May 2014

Emmenegger ME, Frischknecht R, Stutz M, Guggisberg M, Witschi R, Otto T (2006) Life cycle assessment of the mobile communications system UMTS. Int J Life Cycle Assess 11(4):265-267

Ercan EM (2013) Global Warming potential of a smartphone. Master's thesis, Royal Institute of Technology, Stockholm

Ericsson (2013) Mobility report. Ericsson website. http:// www.ericsson.com/TET/trafficView/loadBasicEditor.ericsson. Accesses 29 May 2014

ETSI TS 103199 (2011) European Telecommunications Standards Institute: environmental engineering; life cycle assessment of ICT equipment, networks and services; general methodology and common requirements

Fairphone (2014) Nest step in life cycle assessment: inventory analysis. https://www.fairphone.com/2014/06/20/next-step-in-life-cycleassessment-inventory-analysis/. Accessed July 2014

Falaki H, Mahajan R, Kandula S, Lymberopoulos D, Govindan R, Estrin D (2010) Diversity in smartphone usage, Mobisys 2010

Fishbein BK (2002) Waste in the wireless world: the challenge of cell phones. Inform Inc website. http://informinc.org/reportpdfs/wp/ WasteintheWirelessWorld.pdf. Accessed 29 May 2014

Franke C, Basdere B, Ciupek M, Seliger S (2006) Remanufacturing of mobile phones - capacity, program and facility adaptation planning. Omega: Int J Manag Sci. doi:10.1016/j.omega.2005.01.016

Frey SD (2002) Development of new ecological footprint techniques applicable to consumer electronics. Brunel University, Thesis

Frey SD, Harrison DJ, Billett EH (2006) Ecological footprint analysis applied to mobile phones. J IndEcol 10(1):199-216

Gartner (2013) Gartner says smartphone sales grew 46.5 percent in second quarter of 2013 and exceeded feature phone sales for first time. http://www.gartner.com/newsroom/id/2573415. Accessed August 2014

Geyer R, Blass VD (2010) The economics of cell phone reuse and recycling. Int J Adv Manuf Technol 47:515-525

Geyer R, Oliver J, Amirtarajah V, Akella V (2008) Chong KT (2008) Microchip reuse: environmental rationale and design implications. IEEE Int Symp Electron Environ. doi:10.1109/ISEE.2008.4562926

Gullett BK, Linak WP, Touati A, Wasson SJ, Gatica S, King CJ (2007) Characterisation of air emissions and residual ash from open burning of electronic waste during simulated rudimentary recycling operations. J Mater Cycles Waste Manag 9:69-79

Gutiérrez E, Lozano S, Adenso-Diaz B (2010) Dimensionality reduction and visualization of the environmental impacts of domestic appliances. J Ind Ecolog 14:878-889

Guvendik M (2014) From smartphone to futurephone: assessing the environmental impacts of different circular economy scenarios of a smartphone using LCA. MSc thesis Industrial Ecology, Delft University of Technology and Leiden University

Hageluken C (2006) Improving metal returns and eco-efficiency in electronics recycling. IEEE Int Symp Electr and the Env, p218-223.Doi: 10.1109/ISEE.2006.1650064

Herrmann C (2008) Environmental impact of ICT equipment in manufacture, use and end of life. PE International website. http://www.peinternational.com/uploads/media/Environmental_footprint_of ICT_equipment_01.pdf. Accessed 29 May 2014

HTC (2013) HTC one carbon footprint report. HTC website. http://www. htc.com/assets-desktop/images/csr/tw/download/HTC-One-CFPreport.pdf. Accessed 29 May 2014

Huang EM, Yatani K, Truong KN, Kientz JA, Patel SN (2009) Understanding mobile phone situated sustainability: the influence of local constraints and practices on transferability. IEEE Perv Comput 8:46-53

Huisman J (2004) QWERTY and eco-efficiency analysis on cellular phone treatment in Sweden, TU Delft. https://www.researchgate. net/publication/236879941_QWERTY_and_Eco-Efficiency_ analysis_on_cellular_phone_treatment_in_Sweden?ev=prf_pub. Accessed July 2014

IEA (2013) International Energy Agency Report: CO2 emissions from fuel combustion highlights. http:/www.iea.org/publications/freepublications/ publication/co2emissionsfromfuelcombustionhighlights2013.pdf. Accessed 13 Feb 2015

Inform (2003) Report: Calling all cell phones, collection, reuse and recycling programs in the US

ISO 14040:2006 (2010) Environmental management—life cycle assessment - principles and framework

ISO 14044:2006 (2010) Environmental management—-life cycle assessment-requirements and guidelines

ITU-T L 1410 (2012) International Telecommunications Union: methodology for the assessment of the environmental impact of information and communication technology goods, networks and services

Jang Y-C, Kim M (2010) Management of used and end-of-life mobile phones in Korea: a review. Resour Conserv Recycl 55:11-19

Jayant A (2014) Strategic decision modelling of reverse logistics systems: selection of recovery operations for used cell phones. Res J Econ Bus Stud 3(12):42-62

Judl J, Mattila T, Seppala J, Koskela S, Kautto P (2012) Challenges in LCA comparisons of multifunctional electronic devices. IEEE Electron Goes Green 2012+

Kasper AC, Berselli GBT, Freitas BD, Tenorio JAS, Bernardes AM, Veit HM (2011) Printed wiring boards for mobile phones: characterization and recycling of copper. Waste Manage 31:2536-2545

Kiddee P, Naidu R, Wong MH (2013) Metals and polybrominated dephenyl ethers leaching from electronic waste in simulated landfills. J Hazard Mater 252:243-249

Legarth JB, Salter I, Willum O (2003) Repair or Buy a New One? The environmental consequences for electronics. IEEE Int Symp Electron Environ. doi:10.1109/ISEE.2003.1208076

Li B, Yang J, Song X, Lu B (2012) Survey on disposal behaviour and awareness of mobile phones in Chinese university students. Proc Environ Sci 16:469-476

Lim S-R, Schoenung M (2010) Toxicity potentials from waste cellular phones, and a waste management policy integrating consumer, corporate and government responsibilities. Waste Manage 30:16531660

Lincoln JD, Ogunseitan OA, Shapiro AA, Saphores J-DM (2007) Leaching assessments of hazardous materials in cellular telephones. Environ Sci Technol 41:2572-2578

Maga D, Hiebel M, Knermann C (2013) Comparison of two ICT solutions: desktop PC versus thin client computing. Int J Life Cycle Assess: 18:961-871

Malmodin J, Oliv L, Bergmark P (2001) Life cycle assessment of third generation $(3 \mathrm{G})$ wireless telecommunication systems at Ericsson. 
IEEE Int Symp Environ Conscious Des Inverse Manuf. doi:10. $1109 / .2001 .992375$

Malmodin J, Moberg Å, Lundén D, Finnveden G, Lövehagen N (2010) Greenhouse gas emissions and operational electricity use in the ICT and entertainment \& media sectors. J Ind Ecol 14(5):770-790

Malmodin J, Lundén D, Nilsson M, Andersson G (2012) LCA of data transmission and IP core networks. IEEE Electron Goes Green 2012:1-6

Marukami S, Oguchi M, Tasaki T, Daigo I, Hashimoto S (2010) Lifespan of commodities, part 1: the creation of a database and its review. J Ind Ecol 14(4):598-612

McLaren J, Wright L, Parkinson S, Jackson T (1999) A dynamic lifecycle energy model of mobile phone take-back and recycling. J Ind Ecol 3:77-91

Milovantseva N, Saphores J-D (2013) E-waste bans and U.S. households' preferences for disposing of their E-waste. J Environ Manag 124:8 16

Moberg Å, Borggren C, Ambell C, Finnveden G, Guldbrandsson F, Bondesson A, Malmodin J, Bergmark P (2014) Simplifying a life cycle assessment of a mobile phone. Int J Life Cycle Assess 19:979993

Molto J, Egea S, Conesa JA, Font R (2011) Thermal decomposition of electronic wastes: mobile phone case and other parts. Waste Manage 31:2546-2552

Monteiro MR, Moreira DGG, Chinelatto MA, Nascente PAP, Alcantara NG (2007) Characterisation and recycling of polymeric components present in cell phones. J Polm Environ 15:195-199

Navazo JMV, Mendez GV, Peiro LT (2014) Material flow analysis and energy requirements of mobile phone material recovery processes. Int J Life Cycle Assess 19:567-579

Neira J, Favret L, Fuji M, Miller R, Mahdavi S, Blass VD (2006) End-oflife management of cell phones in the United States. Dissertation, University of California

Nielsen (2013) Prime time is peak time for mobile gaming and social media. Zokem website. http://www.zokem.com/2013/03/primetime-is-peak-time-for-mobile-gaming-and-social-media/. Accessed 29 May 2014

Nnorom IC, Osibanjo O (2009) Toxicity characterization of waste mobile phone plastics. J Hazard Mater 161:183-188

Nnorom IC, Ohakwe J, Osibanjo O (2009) Survey of willingness of residents to participate in electronic waste recycling in Nigeria: a case study of mobile phone recycling. J Clean Prod 17:1629-1637

Nokia (2013a) Eco Profile Nokia 105/Nokia 1050. Nokia website. http:// download.fds-ncom.nokia.com/supportFiles/eco declaration/files/ eco_declaration_phones/105_Eco_profile.pdf. Accessed 29 May 2014

Nokia (2013b) Eco profile Nokia Lumia 720. Nokia website. http:// download.fds-ncom.nokia.com/supportFiles/eco declaration/files/ eco_declaration_phones/Lumia_720_Eco_profile.pdf. Accessed 29 May 2014

Nokia (2013c) Eco Profile Nokia Lumia 1520. Nokia website. http:// download.fds-ncom.nokia.com/supportFiles/eco_declaration/files/ eco declaration phones/Lumia 1520 Eco profile.pdf. Accessed 29 May 2014

Nokia (2015) Reducing the footprint of our products. http://www. microsoft.com/en/mobile/about-us/people-and-planet/sustainabledevices/products/products/. Accessed 2 Feb 2015

OECD (2010) Organisation for Economic Co-operation and Development, Materials Case Study 1: Critical Metals and Mobile Phones. OECD Global Forum on Environment Focussing on Sustainable Materials Management. Oct 2010

Oguchi M, Murakami S, Sakanakura H, Kida A, Kameya T (2011) A preliminary categorization of end-of-life electrical and electronics equipment as secondary metal resources. Waste Manage 31: $9-10$
Ongondo FO, Williams ID (2011a) Greening academia: use and disposal of mobile phones among university students. Waste Manage 31: $1617-1634$

Ongondo FO, Williams ID (2011b) Mobile phone collection, reuse and recycling in the UK. Waste Manage 31:1307-1315

Osibanjo O, Nnorom IC (2008) Material flows of mobile phones and accessories in Nigeria: environmental implications and sound endof-life management options. Environ Impact Assess Rev 28:198213

Paiano A, Lagioia G, Cataldo A (2013) A critical analysis of the sustainability of mobile phone use. Resour Conserv Recycl 73:162-171

Park P-J, Lee K-M, Wimmer W (2006) Development of an environmental assessment method for consumer electronics by combining topdown and bottom-up approaches. Int J Life Cycle Assess 11(4): 254-264

Pew Internet (2013a) Cell phone activities 2013. Pew Research Centre. http://www.pewinternet.org/files/old-media//Files/Reports/2013/ PIP_Cel1\%20Phone\%20Activities\%20May\%202013.pdf. Accessed 30 May 2014

Pew Internet (2013b) Inline Video 2013.Pew Research Centre. http:// www.pewinternet.org/files/old-media//Files/Reports/2013/PIP Online\%20Video\%202013.pdf. Accessed 30 May 2014

Polák M, Drápalová L (2012) Estimation of end of life mobile phones generation: the case study of the Czech Republic. Waste Manage 32: $1583-1591$

Polinares (2012) Polinares Working Paper No. 39 Fact Sheet: Indium. http://www.polinares.eu/docs/d2-1/polinares_wp2_annex2 factsheet5 v1 10.pdf. Accessed 10 Feb 2015

Ponce-Cueto E, Manteca JAG, Carrasco-Gallego R (2010) Reverse logistics practices for recovering mobile phones in Spain. RIRL 2010, The $8^{\text {th }}$ IntConf on Logist and SCM Res

Quariguasi-Frota-Neto J, Bloemhof J (2012) An analysis of the ecoefficiency of remanufactured personal computers and mobile phones. Prod Oper Manag 21(1):101-114

Rathore P, Kota S, Chakrabarti A (2011) Sustainability through remanufacturing in India: a case study on mobile handsets. J Clean Prod 19:1709-1722

Rochat D, Hageluken C, Keller M, Widmer R (2007) Optimal recycling for printed wiring boards (PWBs) in India. R'07 Recover of Mater and Energy for Resour Effic

Sangprasert W, Pharino C (2013) Environmental impact evaluation of mobile phone via life cycle assessment. $3^{\text {rd }}$ IntConf on Chem, Biol and Environ Sci

Santavaara I, Paronen N (2013) Nokia's product life cycle assessment over the years, including challenges and key findings. 6th Int Conf on Life Cycle Manag

Schaefer C, Weber C, Voss A (2003) Energy usage of mobile telephone services in Germany. Energy 28:411-420

Scharnhorst W (2005) Life cycle assessment of mobile telephone networks, with focus on the end-of-life phase. Thesis, Uppsala University

Scharnhorst W, Hilty LM, Jolliet O (2006) Life cycle assessment of second generation $(2 \mathrm{~g})$ and third generation $(3 \mathrm{~g})$ mobile phone networks. Environ Int 32:656-675

Seppälä J, Mattila T (2013) Final Deliverable W6, D6.3: Case Study: Information Technology (Multifunctional Mobile Devices) - Final Sustainability Assessment. ProSuite website. http://www.prosuite. org/c/document library/get file?uuid=9102d135-b389-4bed-9a07a456e0db2214\&groupId $=1 \overline{2} 772$. Accessed 29 May 2014

Silveira GTR, Chang S-Y (2010) Cell phone recycling experiences in the United States and potential recycling options in Brazil. Waste Manage 30:2278-2291

Singhal P (2005) Integrated Product Policy Pilot Project. European Commission website.http://ec.europa.eu/environment/ipp/pdf/ nokia_mobile_05_04.pdf Accessed 29 May 2014 
Soo VK, Doolan M (2014) Recycling mobile phone impact on life cycle assessment. Procedia CIRP 15:263-271

Stutz M, O'Connell S, Pflueger J (2012) Carbon Footprint of a Dell Rack Server. IEEE Electronics Goes Green 2012:1-5

Takahashi KI, Tsuda M, Nakamura J, Otabe K, Tsuruoka M, Matsumo Y, Adachi Y (2009) Elementary analysis of mobile phones for optimizing end-of-life scenarios. iEEE Int Symp on Sustain Syst and Technol. Doi: 10.1109/ISSST.2009.5156682

Tan KCN (2005) Life cycle assessment of a mobile phone. Dissertation, University of Southern Queensland

Tanskanen P (2013) Management and recycling of electronic waste. Acta Mater 61:1001-1011

UNEP (2009) Sustainable innovation and technology transfer industrial sector studies: recycling - from e-waste to resources

Uryu T, Yoshinaga J, Yanagisawa Y (2003) Environmental fate of gallium arsenide semiconductor disposal. J Ind Ecol 7(2):103-112

Wang X, Gaustad G (2012) Prioritizing material recovery for end-of-life printed circuit boards. Waste Manage 32:1903-1913

Weber CL (2012) Uncertainty and variability in product carbon footprinting. J IndEcol 16(2):203-211

West J, Mace M (2010) Browsing as the killer App: explaining the rapid success of Apple's iPhone. Telecomm Pol 34:270-286

Williams ED, Ayres RU, Heller M (2002) The 1.7 kilogram microchip: energy and material use in the production of semiconductor devices. Environ Sci Technol 36:5504-5510

Wong MH, Wu SC, Deng WJ, Yu XZ, Luo Q, Leung AOW, Wong CSC, Luksemburg WJ, Wong AS (2007) Export of toxic chemicals - a review of the case of uncontrolled electronic-waste recycling. Environ Pollut 149:131-140
Wright L (1999) Product life cycle management. Thesis, University of Surrey

Wright L, McLaren J, Jackson T, Parkinson S (1998) Mobile phone takeback and recycling: analysis of the ECTEL Project. IEEE Int Symp Electron Environ. doi:10.1109/ISEE.1998.675030

Wu BY, Chan YC, Middendorf A, Gu X, Zhong HW (2008) Assessment of toxicity potential of metallic elements in discarded electronics: a case study of mobile phones in China. J Environ Sci 20:1403-1408

Yamaguchi H, Tahara K, Itsubo N, Inaba A (2003) A life cycle inventory analysis of cellular phones. 3rd Int Symp on Environ Conscious Des and Inverse Manuf. Doi: 10.1109/ECODIM.2003.1322712

Yamane LH, de Moraes VT, Espinosa DCR, Tenório JAS (2011) Recycling of WEEE: characterization of spent printed circuit boards from mobile phones and computers. Waste Manag 31:2553-2558

Yang (2008) A report on E-waste issues related to mobile telecommunications in China. Mobile Society Research Institute website. http:// www.moba-ken.jp/pdf/research07-02_china_en.pdf. Accesses 30 May 2014

Yang J-X, Wang R-S, Fu H, Liu J-R (2004) Life cycle assessment of mobile phone housing. J Environ Sci 16(1):100-103

Yin J, Gao Y, Xu H (2014) Survey and analysis of consumers' behaviour of waste mobile phone recycling in China. J Clean Prod 65:517-525

Yu J, Williams E, Ju M (2010) Analysis of material and energy consumption of mobile phones in China. Energy Policy 38: 4135-4141

Zink T, Maker F, Geyer R, Amirtharajah R, Akella V (2014) Comparative life cycle assessment of smartphone reuse: repurposing vs. refurbishment. Int J Life Cycle Assess 19(5):1099-1109 